\title{
Glycine Transport by Human Diploid Fibroblasts-Absence of a Defect in Cells from Patients with Nonketotic Hyperglycinemia
}

\author{
JOANN C. KELLY, ELAINE F. OTTO, AND RICHARD E. HILLMAN ${ }^{(28)}$ \\ The Edward Mallinckrodt Department of Pediatrics, Washington University School of Medicine, Divisions of Medical \\ Genetics and Metabolism, St. Louis Children's Hospital, St. Louis, Missouri, USA
}

\begin{abstract}
Summary
Glycine transport in human diploid fibroblasts was shown to be by a single sodium-dependent system. Glycine transport does not appear to exhibit transstimulation or transinhibition. Transport appears to be similar to the $A$ transport system of other mammalian cell lines, as defined by competition patterns. Normal and nonketotic hyperglycinemia (NKH) fibroblasts could not be distinguished on the basis of accumulation or initial rates. A distribution ratio of 15 to 30 was reached by both types of cells. The normal lines have slightly lower apparent $K_{\mathrm{ms}}(1.1-1.3 \mathrm{mM})$ than the NKH lines (1.8 to $2.4 \mathrm{mM}$ ). The values for the $V_{\max }$ of the normal cells (11.4-12.9 nmole/mg/min) and the NKH cells (7.0-16.7 nmole $/ \mathrm{mg} / \mathrm{min}$ ) overlapped. There were no measurable differences in either the long-term incorporation into protein of leucine and glycine or the oxidation of glycine in normal and NKH fibroblasts.
\end{abstract}

\section{Speculation}

In the cell lines used in this study, it does not appear that nonketotic hyperglycinemic fibroblasts contain a glycine transport defect. NKH cells could not be reliably distinguished from normals using transport, incorporation into proteins, or oxidation of glycine.

In mammalian cells neutral amino acids have been shown to be transported by at least three different systems, the A, ASC, and L systems $(2,5,21,22)$, which were distinguished by patterns of competitive inhibition $(1,17,18,21,22)$. The amino acid analog $\alpha$-aminoisobutyric acid (AIB), $\alpha$-methylaminoisobutyric acid (MeAIB), and $\beta$-2-aminobicyclo $(2,2,1)$ heptane-2-carboxylic acid (BCH) have been shown to be specific competitive inhibitors of the A, ASC, and L transport systems, respectively $(4,6,21)$. In human fibroblasts, there appears to exist two distinct systems similar to the L system (15). Glycine has been shown to be transported by a variety of systems $(18,19,20)$. Different mechanisms of glycine uptake exist in various mammalian tissues, e.g., two systems in ascites cells (21) and an iminoglycine system in renal tubules (11). The mechanisms of glycine transport have not been completely defined in human diploid fibroblasts.

Revsin and Morrow (24) have reported that NKH fibroblasts have a reduced rate of uptake and accumulation of glycine as compared to normal human fibroblasts. If such a transport defect existed, it could be a very valuable tool in bettering our understanding of neutral amino acid transport. Identification of the carrier molecule could be greatly assisted if such a natural "mutant" could be found. Therefore, we have examined further the findings reported by Revsin and Morrow (24).

\section{MATERIALS AND METHODS}

Human diploid fibroblasts from skin biopsies from normal and three nonketotic hyperglycinemics were grown in Eagle's minimum essential medium supplemented with $10 \%$ fetal calf serum, penicillin $\left(1 \times 10^{5}\right.$ units/liter), and kanomycin (100 mg/liter). A fourth NKH was also studied less extensively. Upon confluency, cultures were either used in experiments or split 1:3 by trypsinization with $0.25 \%$ trypsin in glycerol containing tris-buffered saline, $\mathrm{pH}$ 7.0. All cells used in these studies were of passage number 6-20. Cells were checked and found to be free of Mycoplasma contamination according to the method of Schneider $e t$ al. (25), which was based on differential uridine-uracil incorporation by human cells and Mycoplasma.

Transport properties were measured in cells grown to confluency on washed, sterile $11-\times 22-\mathrm{mm}$ cover slips as previously described (13). The methods used were similar to those of Foster and Pardee (9) and Platter and Martin (23). Cover slips were washed by dipping in phosphate buffer, $(130 \mathrm{mM} \mathrm{NaCl}, 5 \mathrm{mM}$ $\mathrm{KCL}, 1.2 \mathrm{mM} \mathrm{MgSO}_{4}, 1 \mathrm{mM} \mathrm{CaCl}$, and $10 \mathrm{mM} \mathrm{Na}_{2} \mathrm{HPO}_{4}, \mathrm{pH}$ 7.4) at $37^{\circ}$ before being placed in the incubation medium. Glycine concentrations ranged from $0.075-150 \mathrm{mM}$, at concentrations greater than $10 \mathrm{mM}$, the $\mathrm{NaCl}$ concentration was adjusted to keep the osmolality of the reaction mixture constant. All incubations were at $37^{\circ}$. The initial rates were measured as 1 -min rates. Each datum point represents the mean of at least 10 determinations. Protein was measured on $10 \%$ of the cover slips according to the modified method of Lowry et al. (16). Cell fluid volume was directly related to cell protein, as previously demonstrated (10, 12). A value of $7.86 \mu \mathrm{l} / \mathrm{mg}$ was used as cell fluid volume in the determination of distribution ratios.

Glycine oxidation was measured in fibroblasts as previously described (13). Cell suspensions of $0.5-1 \mathrm{mg} / \mathrm{ml}$ were incubated in phosphate buffer at $37^{\circ}$ for $3 \mathrm{hr}$ in sealed tubes that had been gassed with $100 \%$ oxygen. Glycine was added at the beginning of the incubation period at a concentration of $0.025 \mathrm{mM}$. Each tube contained $2.5 \mu \mathrm{Ci}$ of $\left[1-{ }^{14} \mathrm{C}\right]-,\left[2-{ }^{14} \mathrm{C}\right]$-, or $\left[U-{ }^{14} \mathrm{C}\right]$ glycine. At the end of the incubation period, the tubes were placed on ice, $1 \mathrm{ml}$ NCS was injected into a tube suspended above the incubation mixture to collect the $\mathrm{CO}_{2}$ and $1 \mathrm{ml} 6 \mathrm{~N} \mathrm{H}_{2} \mathrm{SO}_{4}$ was added to the incubation mixture. The tubes were left at room temperature for $2 \mathrm{hr}$ before duplicate samples of NCS were removed for counting in a liquid scintillation counter.

Incorporation of leucine and glycine was measured in confluent cells on cover slips. Cells were labeled with $0.2 \mathrm{mM}\left[{ }^{3} \mathrm{H}\right]$ leucine plus either $\left[1-{ }^{14} \mathrm{C}\right]$ - or $\left[2-{ }^{14} \mathrm{C}\right]$ glycine at a concentration of $0.2 \mathrm{mM}$ for $18 \mathrm{hr}$. The cells were then precipitated and washed twice with ice cold 5\% trichloroacetic acid (TCA) and counted in a liquid scintillation counter.

Growth media and trypsin were purchased from Grand Island Biologicals Co. The fetal calf serum was obtained from Kansas City Biologicals. Cover slips were purchased from Arthur $\mathbf{H}$. Thomas Co. All radiochemicals were purchased from New England Nuclear. The NCS was obtained from Nuclear Chicago Corporation.

\section{RESULTS}

Glycine accumulation was linear for at least $30 \mathrm{~min}$, and glycine continued to accumulate for at least $90 \mathrm{~min}$ (Fig. 1). For the short 
time measurements, less than $5 \mathrm{~min}$, there was no detectable incorporation of glycine into TCA-insoluble material or conversion to serine. However, at longer time points, part of the apparent glycine accumulation could be accounted for by both labeled TCA-insoluble material and labeled serine. The NKH fibroblast lines behaved similarly to the normal lines. Incubation in the presence of $0.1 \%$ glucose did not stimulate either the uptake or incorporation of glycine.

Figure 2 shows the time course of glycine accumulation by normal and NKH cell lines for $30 \mathrm{~min}$. The uptake of glycine in the NKH cells was very similar to that of the controls. A distribution ratio of 15:30 was reached in $30 \mathrm{~min}$ by both types of cells.

Initial rates of glycine uptake as a function of substrate concentration in normal and NKH fibroblasts are shown in Figure 3. After correction for diffusion, as described in a previous report (12), the data form a straight line on a double reciprocal plot. There does not appear to be more than one kinetically distinguishable system for the transport of glycine. The calculated kinetic constants are shown in Table 1. The normal lines had slightly lower apparent $\mathrm{K}_{\mathrm{ms}}(1.1-1.3 \mathrm{mM})$ than the NKH lines (1.8-2.4 $\mathrm{mM})$. The values for the $\mathrm{V}_{\max }$ of the normal cells (11.4-12.9 $\mathrm{nmole} / \mathrm{mg} / \mathrm{min}$ ) and NKH cells $(7.0-16.7 \mathrm{nmole} / \mathrm{mg} / \mathrm{min})$ overlapped. Thus, the normal and NKH lines could not be reliably distinguished on the basis of initial rate kinetic constants.

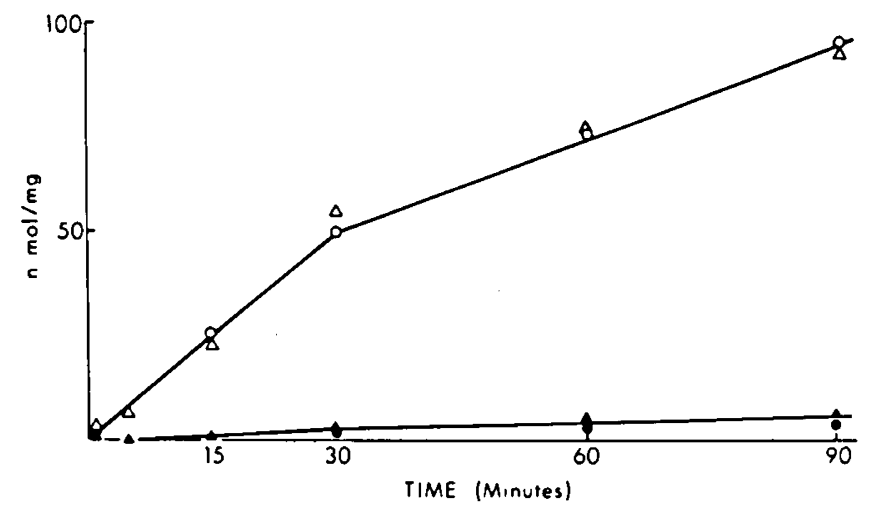

Fig. 1. Glycine accumulation was measured in normal human fibroblasts at a substrate concentration of $0.2 \mathrm{mM}$. Uptake was measured at $37^{\circ}$ in phosphate buffer ( $\mathrm{pH} 7.4$ ) with (triangles) or without (circles) $0.1 \%$ glucose. The open symbols represent total cellular uptake. The solid symbols represent the material that was insoluble in 5\% ice cold TCA. Each point represents the mean of 10 determinations.

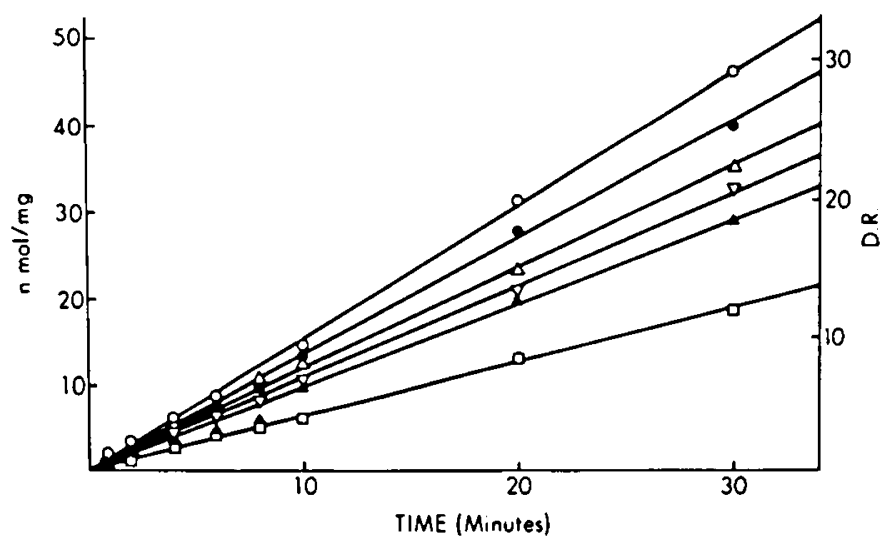

Fig. 2. Glycine accumulation in normal and nonketotic fibroblasts was measured in phosphate buffer, $\mathrm{pH} 7.4$, at $37^{\circ}$ at a substrate concentration of $0.2 \mathrm{mM}$. Cells were rinsed in buffer immediately before uptake. The distribution ratio (D.R.) was calculated from a cell fluid volume of 7.86 $\mu \mathrm{l} / \mathrm{mg}$. The solid symbols are normal cell lines and the open symbols are NKH lines (๑, normal 1; $\Delta$, normal 2; O, NKH; $\square$, NKH 2; $\Delta$, NKH 3). Each point represents the mean of 10 determinations.

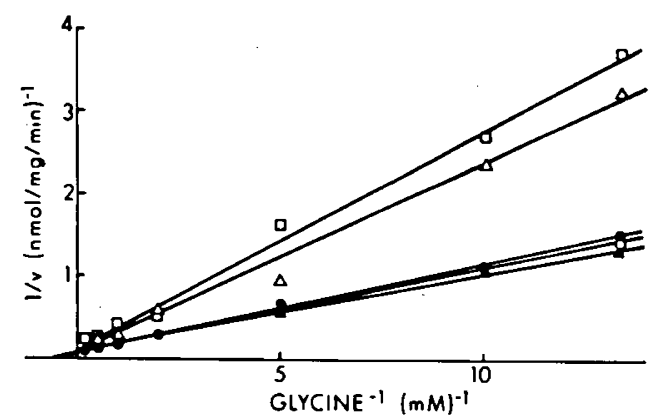

Fig. 3. Initial rates of glycine transport as a function of substrate concentration were measured in normal and NKH fibroblasts. One-min rates were measured in buffer ( $\mathrm{pH} 7.4$ ) at $37^{\circ}$. Cells were rinsed by dipping in buffer immediately before uptake. $\mathrm{V}$ is in nmole $/ \mathrm{mg} / \mathrm{min} ; \mathrm{S}$ is in $\mathrm{mM}$. The solid symbols represent normal lines; the open symbols represent $\mathrm{NKH}$ lines ( $\bullet$, normal $1 ; \boldsymbol{\Lambda}$, normal 2; O, NKH 1; $\square$ NKH 2; $\triangle$, NKH 3).

Table 1. Initial rate kinetics of glycine uptake

\begin{tabular}{lcr}
\hline Cell line & $\mathrm{K}_{\mathrm{m}}{ }^{1}$ & \multicolumn{1}{c}{$\mathrm{V}_{\max }{ }^{2}$} \\
\hline Normal 1 & $1.1 \pm 0.1$ & $11.4 \pm 1.1$ \\
Normal 2 & $1.3 \pm 0.1$ & $12.9 \pm 1.2$ \\
NKH 1 & $1.9 \pm 0.2$ & $7.0 \pm 0.7$ \\
NKH 2 & $2.4 \pm 0.2$ & $9.9 \pm 0.9$ \\
NKH 3 & $1.8 \pm 0.2$ & $16.7 \pm 1.6$ \\
\hline
\end{tabular}

${ }^{1} \mathrm{~K}_{\mathrm{m}}$ is in $\mathrm{mM}$, mean $\pm 1 \mathrm{SD}$.
${ }^{2} \mathrm{~V}_{\max }$ is in $\mathrm{nmole} / \mathrm{mg} / \mathrm{min}$; mean $\pm \mathrm{SD}$.

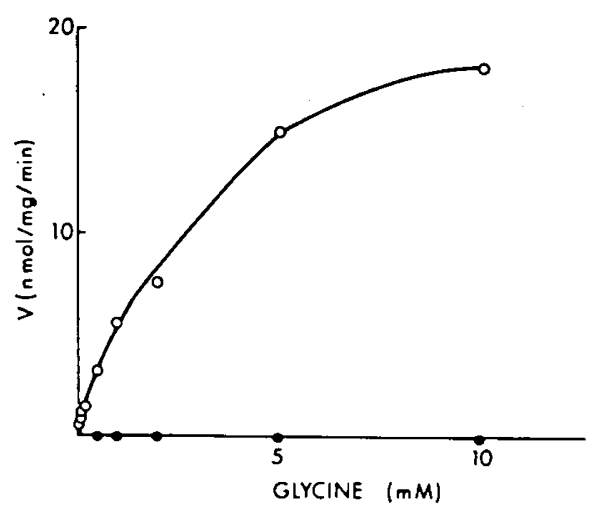

Fig. 4. Initial rates of glycine transport were measured in the presence and absence of sodium. One-min rates were measured at $37^{\circ}$ in phosphate buffer ( $\mathrm{pH}$ 7.4) with sodium or with tris or choline substituted for sodium. Diffusion corrections were made. The open symbols represent results with sodium, the solid symbols are tris or choline substituted for sodium.

The initial rates of glycine transport were measured in the presence and absence of sodium (Fig. 4). In the absence of sodium, there was no measurable uptake of glycine over that which could be contributed to diffusion. Therefore, in human fibroblasts, glycine transport appears to be completely dependent upon the presence of the sodium ion.

As can be seen in Figure 5, preincubation in buffer caused some increase in the rate of glycine uptake. Preincubation with glucose did not cause any further stimulation. Preloading the cells by preincubation in the presence of substrate did not stimulate or inhibit transport over the stimulation seen by preincubation in buffer alone. Glycine transport does not appear to exhibit transstimulation or transinhibition.

In an effect to define the specificity of the transport system that handles glycine, competition patterns were examined (Table 2). Use was made of the amino acid analog AIB, MeAIB, BCH which have been shown to be specific for the A, ASC, and L transport 
systems, respectively, in other mammalian systems. The $\mathrm{L}$ system analog, L-BCH, did not appear to compete at all for glycine uptake. In human fibroblasts, there seems to be very little overlap of specificity for the neutral amino acid transport systems. This is similar to results we have seen using $L$ system substrates (15). The A and ASC analog, AIB and MeAIB, competed for about 35-40\% of the glycine uptake, their effect not being additive. With glycine as substrate, these two systems could not be separated. Further studies with other substrates and competitors may be necessary to determine whether these systems are distinguishable in human fibroblasts. The natural amino acids serine and proline competed for glycine about as well as AIB and MeAIB did. In no combination could more than about one-half of the glycine uptake be removed by competition.

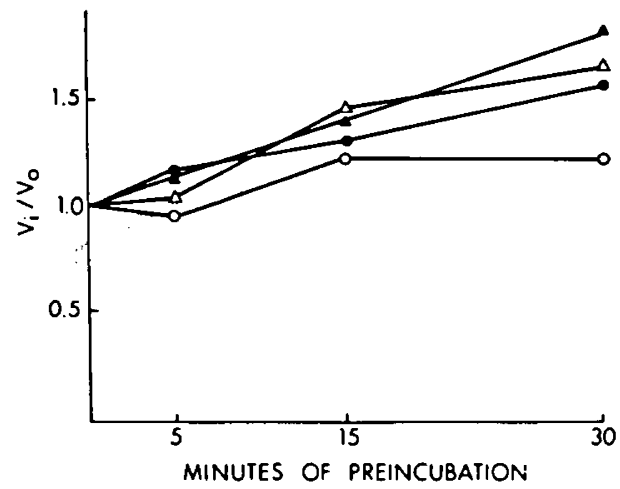

Fig. 5. The effect of preincubation on glycine transport was measured in normal human fibroblasts. Uptake was measured as $1-\mathrm{min}$ rates in phosphate buffer, $\mathrm{pH} 7.4$, at $37^{\circ}$ at a substrate concentration of $0.2 \mathrm{mM}$ glycine. The cells were preincubated for various lengths of time and then rinsed by dipping in buffer before uptake. Preincubations were made in buffer alone (๑), buffer plus $0.1 \%$ glucose $(O)$, buffer plus $2 \mathrm{mM}$ glycine $(A)$, or buffer plus $0.1 \%$ glucose and $2 \mathrm{mM}$ glycine $(\Delta)$. The data are expressed as the ratio of the rate of uptake after the various preincubation times $\left(V_{i}\right)$ over the rate of uptake with no preincubation $\left(V_{0}\right)$.

Table 2. Competition for glycine uptake in normal human fibroblasts

\begin{tabular}{ll}
\hline \multicolumn{1}{c}{ Competitor $^{1}$} & \% Inhibition \\
\hline $2 \mathrm{mM} \mathrm{L-BCH}$ & 0 \\
$2 \mathrm{mM}$ AIB & $37.9 \pm 12.2$ \\
$2 \mathrm{mM}$ MeAIB & $40.2 \pm 14.4$ \\
$2 \mathrm{mM}$ AIB $+2 \mathrm{mM} \mathrm{MeAIB}$ & $34.4 \pm 14.4$ \\
$2 \mathrm{mM}$ AIB $+2 \mathrm{mM} \mathrm{MeAIB}+2 \mathrm{mM} \mathrm{L-BCH}$ & $39.6 \pm 8.6$ \\
$2 \mathrm{mM}$ AIB $+2 \mathrm{mM} \mathrm{L-BCH}$ & $32.3+7.3$ \\
$2 \mathrm{mM}$ L-serine & $37.0 \pm 13.1$ \\
$2 \mathrm{mM}$ L-serine $+2 \mathrm{mM} \mathrm{AIB}$ & $52.5 \pm 13.2$ \\
$2 \mathrm{mM}$ L-proline & $20.8 \pm 8.9$ \\
$2 \mathrm{mM}$ L-proline $+2 \mathrm{mM}$ AIB & $40.3 \pm 13.6$ \\
$2 \mathrm{mM}$ L-proline $+2 \mathrm{mM}$ L-serine & $40.4 \pm 10.3$ \\
$2 \mathrm{mM}$ L-proline $+2 \mathrm{mM}$ L-serine $+2 \mathrm{mM}$ AIB & $43.4 \pm 12.0$ \\
\hline
\end{tabular}

'In all cases, a substrate concentration of $0.1 \mathrm{mM}$ glycine was used. Incubations were for $1 \mathrm{~min}$ in phosphate buffer ( $\mathrm{pH} \mathrm{7.4)}$ at $37^{\circ}$ in the presence of substrate \pm competitor.
In an effort to determine whether differential incorporation of glycine into protein or other metabolic products by normal and nonketotic cells could explain the reported uptake differences (24), long-term incorporation of $\left[{ }^{3} \mathrm{H}\right]$ leucine and $\left[1-{ }^{14} \mathrm{C}\right]-$ or $\left[2-{ }^{14} \mathrm{C}\right] \mathrm{gly}-$ cine was examined (Table 3). The ratios of leucine to glycine incorporation for $\left[1-{ }^{14} \mathrm{C}\right]$ - and $\left[2-{ }^{14} \mathrm{C}\right]$ glycine were very similar (0.27:0.29). There was no measurable difference observed. Similarly, glycine oxidation in normal and NKH fibroblasts was examined and found to be the same for both types of cells (Table 4). Thus, normal and NKH fibroblasts could not be distinguished by the transport properties, incorporation, or oxidation of glycine.

\section{DISCUSSION}

In the human diploid fibroblast lines studied in this laboratory, glycine was accumulated similarly by normal and nonketotic hyperglycinemic cells. Initial rate kinetics (using 1-min rates) demonstrated only one system for the transport of glycine. There were small, but not significant, differences in the apparent $\mathrm{K}_{m s}$ between the normal and NKH cell lines. The $V_{\max }$ values were similar for both types of cells. Although it is possible that a study involving a larger number of cell lines might reveal statistically significant difference in initial rate kinetics, in our study, the normal and NKH lines could not be reliably distinguished on this basis.

When the study of Revsin and Morrow (24) is compared with the present study, uptake of glycine after $20 \mathrm{~min}$ of incubation in $\mathrm{NKH}$ cell lines is seen to be quite similar in the two reports. In both reports, the apparent $\mathbf{K}_{\mathrm{ms}}$ for glycine transport are similar and NKH and normal cell lines are indistinguishable. The differences in the data obtained and their interpretation occur because their normal lines accumulate more glycine after $20 \mathrm{~min}$ than those used here. The apparent $V_{\operatorname{maxs}}$ reported in the Revsin and Morrow study are not easily compared with those reported here because they are not calculated under initial rate conditions. However, if their numbers are expressed in the same units as the present study, then the range of their apparent $\mathrm{V}_{\operatorname{maxs}}$ in NKH cells (9.0-29 $\mathrm{nmole} / \mathrm{mg} / \mathrm{min}$ ) is similar to that reported here, but the range of $V_{\text {maxs }}$ in their normal cell lines (20.5-67.5), although overlapping, is higher than those measured in this laboratory under initial rate conditions.

We attempted to explain these differences by studying glycine incorporation into protein, glycine conversion to serine, and glycine oxidation to $\mathrm{CO}_{2}$. However, no differences could be found between our normal cell lines and NKH cell lines. These findings suggest that some still unexplained metabolic difference exists between the control cell lines used by Revsin and Morrow and those used here. This might occur either because of some nonap-

Table 4. Glycine oxidation in fibroblasts

\begin{tabular}{|c|c|c|c|}
\hline Cell line & {$\left[1-^{14} \mathrm{C}\right]$ Glycine $^{1}$} & {$\left[2-^{14} \mathrm{C}\right]$ Glycine ${ }^{1}$} & {$\left[U_{-}{ }^{14} \mathrm{C}\right]$ Isoleucine ${ }^{1}$} \\
\hline Normal 1 & 89.6 & 10.3 & 345.8 \\
\hline Normal 2 & 50.9 & 7.6 & 140.7 \\
\hline NKH 1 & 57.3 & 7.3 & 222.4 \\
\hline NKH 2 & 51.6 & 9.9 & 236.7 \\
\hline Mother of & 41.5 & 9.8 & 426.3 \\
\hline
\end{tabular}

${ }^{1}$ Picomoles ${ }^{14} \mathrm{CO}_{2}$ produced per milligram protein per $3 \mathrm{hr}$.

Table 3. Leucine and glycine incorporation in human normal and nonketotic fibroblasts

\begin{tabular}{lccccc}
\hline & $\begin{array}{c}\text { Leucine } \\
(0.2 \mathrm{mM})^{1}\end{array}$ & $\begin{array}{c}{\left[1-{ }^{14} \mathrm{C}\right] \mathrm{Glycine}} \\
(0.2 \mathrm{mM})^{1}\end{array}$ & $\begin{array}{c}\text { Leucine/ } \\
{\left[1-{ }^{14} \mathrm{C}\right] \mathrm{Glycine}}\end{array}$ & $\begin{array}{c}{\left[2-{ }^{14} \mathrm{C}\right] \mathrm{Glycine}} \\
(0.2 \mathrm{mM})^{1}\end{array}$ & $\begin{array}{c}\text { Leucine/ } \\
{\left[2-{ }^{14} \mathrm{C}\right] \mathrm{Glycine}}\end{array}$ \\
\hline Normal 1 & 10.7 & 40.0 & 0.27 & 37.4 & 0.29 \\
Normal 2 & & 48.1 & & 43.9 & \\
NKH 1 & 17.5 & 61.0 & 0.29 & 62.1 & 0.28 \\
NKH 2 & & 40.0 & & 36.3 & \\
\hline
\end{tabular}

\footnotetext{
${ }^{1} \mathrm{nmole} / \mathrm{mg}$ incorporated in $18 \mathrm{hr}$.
} 
parent difference in methodology or because of genetic heterogeneity in the control or NKH cell lines. This latter possibility might allow some NKH cell lines to be distinguished on the basis of glycine accumulation.

Glycine transport in human diploid fibroblasts appears to be similar to transport by the A system of other mammalian cell lines (21-22). Kinetically, there appears to be a single transport system which is highly sodium dependent. The system has a high affinity for glycine and is specific for the short-chain neutral amino acids. Furthermore, this system does not appear to be easily transstimulated or transinhibited by altering intracellular pools by preincubation.

\section{REFERENCES AND NOTES}

1. Ahmed, K., and Scholefield, P. G.: Biochemical studies on I-aminocyclopentane carboxylic acid. Can. J. Biochem. Physiol., 40: 1101 (1962).

2. Christensen, H. N.: Biological Transport, p. 174-211 (W. A. Benjamin, Inc., Reading 1975).

3. Christensen, H. N.: Some transport lessons taught by the organic solute. Perspect. Biol. Med., 10: 471 (1967).

4. Christensen, H. N., Handlogten, M. E., Lam, I., Tager, H. S., and Zand, R.: A bicyclic amino acid to improve discriminations among transport systems. J. Biol. Chem., 244: 1510 (1969).

5. Christensen, H. N., Liang, M., and Archer, E. G.: A distinct $\mathrm{Na}^{+}$-requiring transport system for alanine, serine, cysteine, and similar amino acids. J. Biol. Chem., 242: 5237 (1967).

6. Christensen, H. N., Oxender, D. L., Liang, M., and Vatz, K. A.: Use of NMethylation to direct the route of mediated transport of amino acids. J. Biol. Chem., 240: 3609 (1965).

7. Eavenson, E., and Christensen, H. N.: Transport systems for neutral amino acids in the pigeon erythrocyte. J. Biol. Chem., 242: 5386 (1967).

8. Finerman, G. A. M., and Rosenberg, L. E.: Amino acid transport in bone. J. Biol. Chem., 241: 1486 (1966).

9. Foster, D. O., and Pardee, A. B.: Transport of amino acids by confluent and nonconfluent $3 \mathrm{~T} 3$ and polyoma virus-transformed $3 \mathrm{~T} 3$ cells growing on glass coverslips. J. Biol. Chem., 244: 2675 (1969).

10. Groth, U., and Rosenberg. L. E.: Transport of dibasic amino acids, cystine and tryptophan by cultured fibroblasts: Absence of a defect in cystinuria and Hartnup disease. J. Clin. Invest., 51: 2130 (1972).
11. Hillman, R. E., Albrecht, I.. and Rosenberg, L.: Identification and analysis of multiple glycine transport systems in isolated mammalian renal tubules. J. Biol. Chem., 243: 5566 (1968).

12. Hillman, R. E., and Otto, E. F.: Transport of L-isoleucine by cultured fibroblasts. J. Biol. Chem.. 249: 3430 (1974).

13. Hillman, R. E., Sowers, L. H., and Cohen, J. L.: Inhibition of glycine oxidation in cultured fibroblasts by isoleucine. Pediatr. Res., 7: 945 (1973).

14. Inui, J., and Christensen, H. N.: Discrimination of single transport systems. The $\mathrm{Na}^{+}$-sensitive transport of neutral amino acids in the Ehrlich cell. J. Gen. Physiol., 50: 203 (1966).

15. Kelly, J. C., Otto, E. F., and Hillman, R. E.: High affinity isoleucine transport in human fibroblasts-Absence in a transport deficient cell line (submitted for publication).

16. Lowry, O. H., Rosebrough, N. J., Farr, A. F., and Randall, R. J.: Protein measurement with folin phenol reagent. J. Biol. Chem., 193: 265 (1951).

17. Matthews, R. H.: Characteristics of a transport system serving for the transfer of histidine into S37 ascites tumor cells. Biochim. Biophys. Acta, 282: 374 (1972).

18. Matthews, R. H., Sardina, M., Lewis, N. J., and Zand, R.: Biophasic kinetic plots and specific analogs distinguishing and describing amino acid transport sites in S37 ascites tumor cells. Biochim. Biophys. Acta, 394: 182 (1975).

19. Munck, G. B.: Amino acid transport by the small intestine of the rat. Biochim. Biophys. Acta, 120: 97 (1966).

20. Nelson, K. M., and Lerner, J.: A distinct $\mathrm{Na}^{+}$-dependent glycine transport system in avian small intestine. Biochim. Biophys. Acta, 203: 434 (1970).

21. Oxender, D. L., and Christensen, H. N.: Distinct mediating systems for the transport of neutral amino acids by the Ehrlich cell. J. Biol. Chem., 238: 3686 (1963).

22. Oxender, D. L., Lee, M., Moore, P. A., and Cecchini, G.: Neutral amino acid transport systems in tissue culture cells. J. Biol. Chem., 252: 2675 (1977).

23. Platter, H., and Martin, G. M.: Tryptophan transport in cultures of human fibroblasts. Proc. Soc. Exp. Biol. Med., 123: 140 (1966).

24. Revsin, B., and Morrow, G.: Glycine transport in normal and nonketotic hyperglycinemic human diploid fibroblasts. Exp. Cell Res., 100: 95 (1976).

25. Schneider, E. T., Stanbridge, E. J., and Epstein, C. J.: Incorporation of ${ }^{3} \mathrm{H}$-uridine and ${ }^{\mathrm{H}} \mathrm{H}$-uracil into RNA. Exp. Cell Res., 84: 311 (1974).

26. The authors thank Mrs. Sabra Lovejoy for her assistance in preparing this manuscript and Dr. Carl H. Smith for his generous gift of the BCH.

27. This research was supported by USPH Grant AM 15531 and the Ranken Jordan Trust Fund for the Crippling Diseases of Children.

28. Requests for reprints should be addressed to: Dr. Richard E. Hillman, Department of Pediatrics, St. Louis Children's Hospital, 500 So. Kingshighway, P.O. Box 14871, St. Louis, MO 63178 (USA).

29. Received for publication January 3, 1978.

30. Accepted for publication March 13, 1978. 